\title{
Den største utfordring til forebyggende helsearbeid
}

\author{
Kjell Bjartveit \\ Statens helseundersøkelser, Postboks 8155 Dep, 0033 Oslo
}

\begin{abstract}
SAMMENDRAG
Antall årlige dødsofre av tobakksrøyking anslås nå til 3 millioner (alle land samlet); i 2025 vil det være 10 millioner, hvis ikke røykemønstret endres. Storstilt global forebyggende innsats har latt vente på seg, vesentlig p.g.a. tobakksindustriens motstand og myndighetenes lunkenhet.

Det er påvist virkning av en rekke tiltak, bl.a. reklameforbud, helseadvarsler på pakkene, avgiftsøkninger og røykerestriksjoner. For å skape et effektivt program er det nødvendig med solid faglig ekspertise, sterke pressgrupper, engasjerte byråkrater og handlekraftige politikere.

Canada har for tiden det mest avanserte program. Norge lå bra an i 1970-årene, men sakket noe av i 80-årene. Tobakksforbruket steg inntil ca. 1975, men er falt senere. Det samme gjelder prosent dagligrøykere blant elever i grunnskolen. Det har vært en nedgang i dagligrøyking blant menn; blant kvinner er det hittil liten endring, unntatt blant de yngste, som har nedgang.

Utviklingen i de fattige landene er mest bekymringsfull. Norske politikere burde være pådrivere for å få FN til å vedta en internasjonal konvensjon om tobakkskontroll.
\end{abstract}

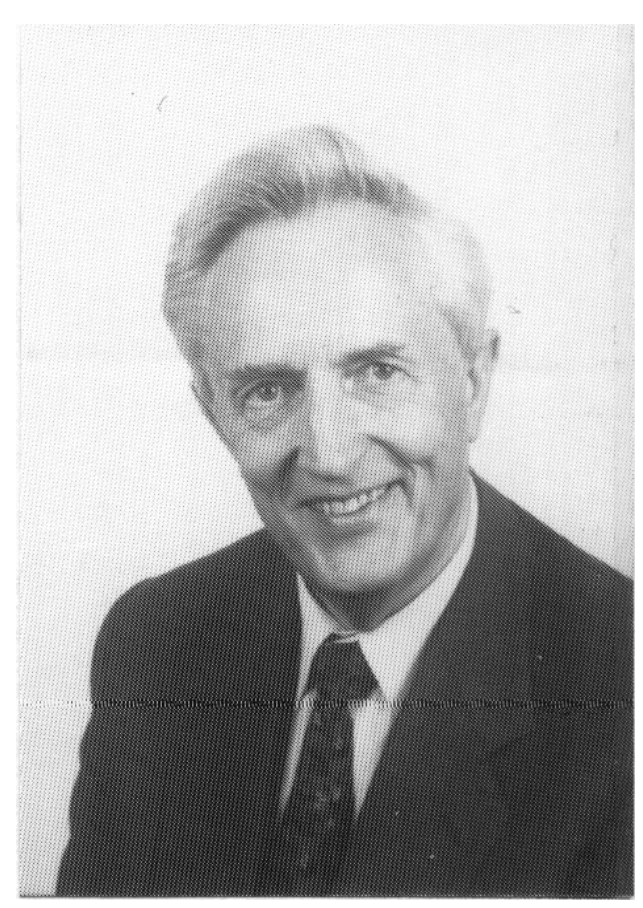

Administrerende overlege, dr.med. Kjell Bjartveit, Statens helseundersøkelser

Bjartveit K. The greatest challenge to preventive health work. Nor J Epidemiol 1995; 5 (2): 93-106.

\section{ENGLISH SUMMARY}

It is estimated that, worldwide, three million people die every year as a result of tobacco smoking. This number will increase to 10 million by year 2025 if today's pattern of smoking continues. Large-scale global preventive action is long in coming, mainly due to resistance of the tobacco industry and a lukewarm attitude on the part of national governments.

Various measures, such as a ban on advertising, health warnings on packaging, tax increases and restrictions on smoking, have been shown to work. Prerequisites for an effective programme are highly qualified professional expertise, strong pressure groups, dedicated bureaucrats and energetically involved politicians.

Canada has the most advanced programme at present. Norway's efforts compared favourably in the 1970s, but slowed down in the 1980s. Per capita tobacco consumption increased up to about 1975, but has since declined. The same applies to the percentage of smokers in the lower secondary schools. The prevalence of daily smoking has declined among men; little change has been observed in women, except in the youngest age group, where smoking has decreased.

Developments in the poor countries of the world give greatest cause for concern. Norwegian politicians should actively urge the United Nations to adopt an international convention on tobacco control. 


\section{PROBLEMET: BARE VERRE OG VERRE ...}

Til å begynne med snakket man bare om lungekreft.

Egentlig startet det hele i 1947 da Medical Research Council i Storbritannia arrangerte en konferanse om den sterkt stigende dødelighet av sykdommen (1). Austin Bradford Hill var da nettopp tiltrådt som rådets forskningsdirektør ved London School of Hygiene and Tropical Medicine, og en av hans nyrekrutterte medarbeidere var Richard Doll. De satte i gang en stor "case-control-studie", og publiserte resultatene i 1950 (2). Mange mulige årsaker ble inkludert i studien. Doll selv trodde den gangen at den økende biltrafikk var synderen, og det kom som en overraskelse på ham at den eneste klare forskjell mellom dem som hadde lungekreft og dem som ikke hadde det, var at nesten alle med lungekreft hadde vært røykere.

Dette ga støtet til den berømte britiske legeundersøkelsen, som begynte i 1951, og som omfatter 40000 britiske leger - den første store prospektive studie i verden om røyking og død ${ }^{*}$. De første resultatene kom i midten av 50-årene, $(3,4)$. Nå var det ikke lenger bare lungekreft som viste sammenheng med røyking, men også kronisk bronkitt, hjertekarsykdom og andre lidelser. Tobakk svarte for nesten alle dødsfall av lungekreft, og i tillegg for et endog større antall dødsfall av andre sykdommer.

I 1976 publiserte Doll - sammen med sin unge medarbeider Richard Peto - resultatene av 20 års oppfølging av materialet (5). Her ble det vist at totaldødeligheten blant middelaldrende menn var dobbelt så stor blant røykere som blant ikke-røykere.

Men det skulle bli enda verre.

I 1994 presenterte Sir Richard Doll - 82 år gammel - resultatene av 40 års oppfølging av materialet (6). Her heter det i konklusjonen:

"Results from the first 20 years of this study, and of other studies of that time, substantially underestimated the hazards of long term use of tobacco. It seems that about half of all regular cigarette smokers will eventually be killed by their habit."

I alt ble 24 dødsårsaker funnet å være positivt assosiert med sigarettrøyking, og én negativt

\footnotetext{
${ }^{*}$ Epidemiologer bør merke seg hvorledes Sir Austin Bradford Hill introduserte studien i BMJ den 10. november 1951: "Last week I sent a letter personally to every man and woman on the medical register of the UK asking them to help me." Han ba dem om å fylle ut et enkelt skjema om deres røykevaner, for at han senere kunne relatere dette til fremtidig død. "This, I think, is a new method of approach looking forwards in a normal population rather than backwards in declared patients" (kilde: Editor's choice: A 44 year campaign, but the epidemic is growing. BMJ 1994; 309: 887).
}

(Parkinsons sykdom). "Excess mortality" var omtrent dobbelt så høy i andre halvdel som i første halvdel av studien. Peto har utdypet resultatene ytterligere (1):

"About half of teenagers who keep smoking steadily will be killed by tobacco (about a quarter in old age plus a quarter in middle age). Those killed by tobacco in middle age (35-69) lose on average 20-25 years of nonsmoker life expectancy".

En lang rekke epidemiologiske undersøkelser - først og fremst i USA - har kommet til samme resultater som de britiske. Også norske forskere var tidlig ute, og arbeider fra bl.a. Leiv Kreyberg (7) gjorde seg bemerket $\mathrm{i}$ internasjonal sammenheng. I dette nummer av Norsk Epidemiologi får vi en revy av norsk forskning pr. i dag på dette feltet.

Status pr. idag gir oss likevel bare toppen av isfjellet. I store befolkningsgrupper er røykingen fortsatt på opptur - blant kvinner og i den fattige del av verden. I årene som kommer, vil de måtte betale prisen. Hvert år dør nå tre millioner av røyking -2 millioner $\mathrm{i}$ industrialiserte land og 1 million $\mathrm{i}$ de fattige landene. Peto, Gomez og medarbeidere har estimert antall røykedødsfall for år 2025, forutsatt at røykemønsteret fortsetter som nå (8). Da vil det være 10 millioner pr. år som dør av røyking - tre millioner $\mathrm{i}$ industrialiserte og 7 millioner $\mathrm{i}$ fattige land. I de industrialiserte land lever det i dag 200 millioner som i fremtiden vil dø som følge av deres tobakksbruk (1), 100 millioner av dem før de fyller 70 år.

Vi står overfor den verste epidemi i vår tid.

Det mest tragiske er at disse spådommer ser ut til å gå i oppfyllelse, til tross for at dette kan unngås hvis bruken av tobakk opphører nå. Doll og Peto peker på at de som stumper røyken før de fyller 35 år, har en levealder som ikke er forskjellig fra ikke-røykernes (6).

\section{STOR UTFORDRING - LUNKEN RESPONS}

På denne dystre bakgrunn skulle vi ha ventet et gigantisk, aggressivt og globalt forebyggende program for å stoppe denne pandemien, skapt av mennesker i vårt århundre. Saken burde vært tatt opp på høyeste plan i FN - ikke bare i WHO - og det burde vært utarbeidet en konvensjon som alle landene skulle ha forpliktet seg på. Konvensjonen burde ha krevd målrettet og helhjertet innsats med anvendelse av hele registeret av mulige tiltak. Og ikke bare det, den burde også ha tatt opp de kompliserte spørsmål knyttet til jordbruk og handel - med bl.a økonomisk støtte til fattige tobakksbønder for å legge om produksjonen til andre vareslag.

Men hva har skjedd? I grunnen ganske lite. Det har ikke manglet på pompøse erklæringer. Allerede i 1975 fremhevet en WHO ekspertkomite at 
"- the control of cigarette smoking could do more to improve health and prolong life ... than any single action in the whole field of preventive medicine" (9).

Liknende kraftsatser har kommet i tur og orden, også fra politisk hold.

Likevel har det skortet på den totale innsats. I stedet for akselererende tiltak og adekvate bevilgninger til informasjonsarbeidet ser vi ofte eksempler på det motsatte: I 1993 bevilget EU 1,17 milliarder Ecu, tilsvarende 9,44 milliarder norske kroner, som subsidier til tobakksproduksjon, dvs. $1,8 \%$ av Unionens totale budsjett (10). Ingen annen sektor innenfor jordbruket fikk så store subsidier. Man kunne håpet på at denne summen ble brukt til å hjelpe bøndene til å legge om driften til andre produkter. Men nei, bare 3\% ble brukt til dette formål (European Bureau for Action on Smoking Prevention (BASP), Brussel, personlig meddelelse).

Det er ingen tvil om at årsaken til denne lunkne holdningen langt på vei skyldes den kolossale lobbyvirksomheten som tobakksindustrien har bombardert verdens styresmakter med. Forebyggende tiltak er blitt effektivt motarbeidet av denne industri, som har nærmest ubegrensede ressurser til disposisjon. Hva den samlede lobbyvirksomhet beløper seg til, er ikke kjent, men det årlige globale beløp bare til reklame og "sales promotion" dreier seg om over 5 milliarder dollar (1). Denne groteske situasjonen viser hvilket alvorlig handicap som er knyttet til tobakksarbeidet $\mathrm{i}$ forhold til annen forebyggende virksomhet. I tuberkulosearbeidet f.eks. har vi i så måte hatt lett match; det er ingen som lever av å selge tuberkelbasiller.

Tobakksindustrien har dessuten sterke allierte blant røykerne selv, fordi det produktet de selger, er avhengighetsskapende. Dette forhold har alltid vært benektet av tobakksindustrien; fra en høring i 1994 i den amerikanske kongressen foreligger det et patetisk bilde av alle "chief executives" i de syv største amerikanske tobakksfirmaer, som med hevet høyre hånd sverger å fortelle den hele og fulle sannhet hvoretter alle avviser at tobakksrøyking skaper avhengighet. Fra WHO og andre helseautoriteter er det derimot fremhevet med økende styrke at bruk av tobakk skaper avhengighet (11), og i flere land omfatter advarselstekstene på tobakkspakkene også dette budskap. Sannheten er at når et barn eller en ungdom begynner å røyke, har industrien gjerne fått seg en kunde for livet - pga. avhengigheten.

\section{PROBLEMET KAN PÅVIRKES}

Finnes det så tiltak som kan redusere tobakksforbruket?

La det med en gang slås fast at vår viten på dette felt er begrenset, og at det stadig er behov for storstilt og systematisk forskning for å finne fram til de mest effektive kombinasjoner av virkemidler.

Like fullt, noe vet vi. Vi skal se på de mest aktuelle tiltak hvor det er påvist positive virkninger.

\section{(1) Opplysningsarbeid og avvenningstiltak}

Informasjon må hele tiden være fundamentet for alt tobakksforebyggende arbeid. En viktig funksjon av opplysningsarbeidet er å heve befolkningens - og styresmaktenes - kunnskapsnivå om det enorme helseproblem vi står overfor, og å skape positive holdninger til de restriktive tiltakene; folk må forstå hvorfor de er nødvendige.

Har så opplysningsarbeidet hatt noen direkte virkning på røykevanene? Erfaringene fra tallrike opplysningskampanjer har vært delte. Jøsendal og Aarø's artikkel i dette nummer av Norsk Epidemiologi (12) gir dog grunn til optimisme når det gjelder godt funderte, skolebaserte intervensjoner.

Informasjon skaper behov for lett tilgjengelig avvenningstilbud for folk som ikke greier å slutte på egen hånd. Vi merket det særlig i slutten av 1970årene da en sterk britisk film, "Dying for a fag", ble vist tre ganger på norsk fjernsyn. Filmen resulterte i en storm av henvendelser fra alle kanter av landet: Hjelp meg til å slutte!

Effektivt informasjonsarbeid er meget kostbart og jeg har liten tro på at det vil lykkes noen helseminister å skaffe de nødvendige midler innenfor de ordinære budsjettrammer som Finansdepartementet stiller til rådighet. Skal tilstrekkelige midler skaffes, er det bare én vei å gå: en øremerket tilleggsavgift på tobakksvarene. Dette er imidlertid ofte tabu blant mange norske politikere og byråkrater, som selv ønsker å bestemme hvilke satsningsområder som skal prioriteres når tilgjengelige midler skal fordeles.

Forslaget om øremerkede midler ble tatt opp allerede i slutten av 1960-årene av Landsforeningen mot Kreft, som med formannen professor Olaf Torgersen i spissen avla regjeringskontorene et besøk i sakens anledning. Senere er forslaget tatt opp flere ganger, sist av professor Leif Edvard Aarø, som i en utmerket rapport går inn for at de ekstra midler skal anvendes til helseopplysning generelt (13).

Holdningene mot øremerkede avgifter er trolig så rigide at jeg dessverre må melde min pessimisme mht mulighetene for å få forslaget gjennom. Kanskje kunne vi nå frem hvis vi begrenset formålet til tobakksforebyggende arbeid, og hvis ekstra-avgiften ble så lav som én øre pr. sigarett og tilsvarende for andre tobakksformer. Det ville likevel gi nær 60 millioner kroner årlig, og det ville være en brukbar start. Begrunnelsen overfor styresmaktene måtte være at vi nå står overfor en krisesituasjon som krever krisetiltak.

Faste andeler av de ekstra midler burde gå til kommunenes eget opplysningsarbeid, til de frivillige organisasjoner, og til forskning om tobakksfore- 
byggende tiltak. En forutsetning burde være at alle mottakere selv dekker en bestemt del av budsjettet for det planlagte prosjektet - en modell kunne hentes fra NORAD's praksis: frivillige organisasjoner må selv dekke 20\% før NORAD dekker de resterende $80 \%$. Dermed har myndighetene en viss sikkerhet for påholden anvendelse av pengene, og for nødvendig engasjement hos brukerne.

\section{(2) Reklameforbud}

Mer enn 20 land har nå innført totalt reklameforbud. I Storbritannias helsedepartement er det foretatt en analyse av reklameforbudets virkning i fire av disse landene. Det er justert for en rekke andre faktorer som kan ha influert på utviklingen (14). Konklusjonen er at forbudet har ført til følgende reduksjon i forbruket: Norge $9 \%{ }^{*}$, Finland 6,7\%, Canada $4 \%$ og New Zealand 5,5\%. Om Norge sier rapporten:

"It is not possible to quantify precisely the share of this reduction attributable to the advertising ban itself, but, in view of the minor nature of the other provisions of the Act, the ban on advertising is likely to have accounted for the great majority of the effect."

Reklameforbudene kan neppe stoppe den massive påvirkning gjennom film og fjernsyn, hvor sigaretten har vært en del av idolenes image. Men forbudene kan ha en normskapende effekt, som kan gi mindre røyking i filmene. Det er iallfall påfallende mindre røyking nå enn da Humphrey Bogart, John Wayne og Yul Brynner var i aksjon.

\section{(3) Helseadvarsler på tobakkspakkene}

Det var Sverige som fant opp systemet med roterende helseadvarsler, dvs. at en rekke forskjellige tekster finnes på pakkene som er i salg, og at disse tekstene både innhold og design - skifter hyppig. Undersøkelser før og et år etter at dette systemet ble innført i 1977, viste en signifikant økning i kunnskapene knyttet til budskapene i tekstene. Denne økningen var særlig uttalt blant røykerne, som tekstene var rettet til. Samtidig kom det en klar reduksjon i røykeprosenten i den voksne svenske befolkning (15).

Dette resultat ble observert til tross for at de svenske advarselstekstene ikke tilfredsstilte de krav som i dag blir satt opp: At tekstene plasseres på toppen av begge hovedflater av pakkene, at de dekker $25 \%$ av disse flatene, at de trykkes med svart skrift mot hvit bakgrunn og med en tydelig ramme rundt, og at de bringer et budskap som angår folk direkte og gir troverdig informasjon (16).

Fra Canada er det vist at helseadvarslene er en viktig informasjonskilde om skadevirkningene av

\footnotetext{
* Rapporten gir to estimater for Norge; en annen modell gir $16 \%$ reduksjon i forbruket.
}

røyking, denne kilde rangerer faktisk som nr. 2 etter fjernsyn (17).

I enkelte land diskuteres det nå å innføre såkalt "plain packaging", dvs at alle pakker må ha ensartet utforming uten bruk av reklameeffekter, med merkenavnet i standard størrelse og typer, og med helseadvarsler i overensstemmelse med ovennevnte krav. På oppdrag av den kanadiske helseminister ble det i mai 1995 lagt frem en 300 siders forskningsrapport om dette systemet (18). Konklusjonen var at dette tiltaket "would likely depress the incidence of smoking uptake by non-smoking teens, and increase the incidence of smoking cessation by adult smokers."

\section{(4) Avgiftsøkninger}

Studier fra mange land har vist at tobakksforbruket er sensitivt overfor endringer i prisene $(19,20)$. En dyptpløyende analyse kommer fra Finland, hvor estimatene er justert for andre variabler som kan ha påvirket konsumet. Denne studie finner en priselastisitet på $-0,49$, hvilket betyr at en økning i sigarettprisen på f.eks. $10 \%$ vil gi nær $5 \%$ reduksjon i forbruket (21). Liknende resultater er funnet i USA: for hver $10 \%$ økning i prisen, vil det komme $4 \%$ reduksjon i forbruket (22).

Dette innebærer at en prisøkning som overstiger økningen i kjøpekraften, automatisk vil føre til en reduksjon i etterspørselen. På den annen side, hvis styresmaktene bestemmer seg for ikke å la tobakksprisen følge økning i kjøpekraften, har de i realiteten bestemt seg for en økning i forbruket. Og å fortsette med det tollfrie salget betyr i prinsippet det motsatte av en målrettet prispolitikk.

Priselastisiteten varierer betydelig mellom undergrupper i befolkningen. En amerikansk studie har vist at tenåringer er særlig sensitive for prisøkninger: En økning på $10 \%$ i pris vil gi $14 \%$ reduksjon i forbruk i alder 12-17 år, mot 4,5\% i alder 36-74 år (23). En studie fra Storbritannia kunne ikke påvise en liknende aldersgradient, derimot ble det funnet en signifikant lineær gradient etter sosialgruppe; i sosialgruppe 5 var priselastisiteten $-1,0$ for menn og $-0,9$ for kvinner, mens den i sosialgruppe 1 og 2 ikke var signifikant forskjellig fra 0 (24). Analysen inkluderte også virkningen av "health publicity", som ble definert som nettoeffekten av helseopplysning, sosial akseptabilitet og røykerestriksjoner på arbeidsplassen og på offentlig sted. Her gikk tendensen i motsatt retning: menn og kvinner i lavere sosialgrupper var mindre sensitive enn de i høyere sosialgrupper. Kvinner var, sammenliknet med menn, mindre sensitive overfor "health publicity" og mer overfor prisøkninger.

\section{(5) Regler om røykfritt innendørs offentlig miljø}

Formålet med slike bestemmelser er vern mot kort- og langsiktige virkninger av ufrivillig passiv røyking. Bedret trivsel vil være en umiddelbar effekt, og resultater fra norske undersøkelser taler for at dette er 
oppnådd: I 1992 var det $39 \%$ av den voksne befolkning som mente at trivselen hadde økt etter at "Røykeloven" trådte i kraft i 1988 (25). 53\% mente at trivselen var uendret, og $4 \%$ at den var blitt redusert. Endog blant røykerne var det en tydelig, om enn ikke så uttalt, økning i trivselen.

Redusert forbruk kan være en tilleggseffekt av røykerestriksjonene. I 1989 i Sør-Australia ble personer 15 år og over intervjuet om sigarettforbruket på en typisk fridag og en typisk arbeidsdag (26). Blant røykere uten røykerestriksjoner på arbeidsstedet var det ingen forskjell i forbruket på disse dagene. Blant røykere med restriksjoner var forbruket ca. 5 sigaretter mindre på arbeidsdager sammenholdt med fridager. Fem sigaretter mindre pr. arbeidsdag betyr 1150 sigaretter mindre pr. år.

\section{(6) Aldersbegrensninger}

Dette tiltaket er gjennomfort i mange land, men håndhevingen har ofte vært mangelfull. I Woolridge, Illinois, ble det i mai 1989 forbudt å selge tobakk til personer under 18 år, og systematisk og omfattende oppfølging sikret at butikkene gjennomførte bestemmelsene. Spørreundersøkelser før og etter aldersbegrensningene ble innført, viste markert reduksjon $\mathrm{i}$ røykingen blant 7. og 8. klassingene i "junior high school": fra mars 1988 til april 1991 falt prosenten av dem som hadde eksperimentert med røyking fra 46 til 23, og av vanerøykere fra 16 til 5 (27).

\section{(7) Reduksjon av tilgjengeligheten}

Ut fra generelle betraktninger om at redusert tilgjengelighet burde gi redusert etterspørsel, skulle man anta at forbruket kunne påvirkes ved å la bare tobakksbutikker med lisens selge tobakk, og å begrense salget til definerte tider. Ingen land har innført slike bestemmelser, fortsatt kan tobakk kjøpes døgnet rundt, mens f.eks. ølsalget stopper til fastsatt klokkeslett.

Én form for redusert tilgjengelighet er imidlertid innført i enkelte land: forbud mot sigarettautomater. Tiltaket har særlig vært rettet mot ukontrollert salg til mindreårige. Såvidt vites, foreligger det hittil ingen evaluering av tiltaket.

\section{(8) Reduksjon av skadelige stoffer i røyken}

Blant røykere av lavtjæresigaretter er det påvist noe lavere lungekreftdødelighet enn blant røykere av høytjæresigaretter. For hjerteinfarkt, den røykesykdom som tar flest liv, er konklusjonene mer usikre - under enhver omstendighet er forskjellen i risiko langt større mellom røykere og ikke-røykere, enn mellom røykere av sigaretter med middels og lavt tjæreinnhold (28).

I flere land er det innført øvre grenser for tjære- og nikotininnholdet i røyken, f.eks vil landene i EU (og med EØS-avtale) ha $12 \mathrm{mg}$ tjære pr. sigarett som øvre grense innen 31. desember 1997 (Rådsdirektiv
90/239/EØF). I hvilken utstrekning slike grenser påvirker konsumet $\mathrm{i}$ en befolkning, er såvidt vites ikke utredet. En mulig uheldig virkning kan være såkalt kompensatorisk røyking, dvs. at dagsforbruket eller inhalasjonsgraden økes, og at stumplengden minskes, for å tilfredsstille nikotintrangen. En annen negativ virkning kan være at tiltaket skaper falsk trygghetsfølelse, dvs at folk tror at de nå røyker "sikre" eller "nesten sikre" sigaretter, og dermed at motivasjonen svekkes for det eneste sikre alternativ: å stumpe røyken.

\section{(9) Forbud mot "smokeless tobacco"}

Den mest alminnelige av disse vareslagene er snus, som hittil har vært på markedet $\mathrm{i}$ et begrenset antall land. Hong Kong var tidlig ute med forbud mot snussalg, og hindret dermed amerikansk tobakksindustri fra å introdusere snus i kronkolonien. Senere har andre snus-frie land innført liknende bestemmelser, og i EUs rådsdirektiv 92/41/EØF heter det i artikkel 8a: "Medlemsstatene skal forby omsetning av tobakk til oral bruk ...". Sverige - med verdens største snusforbruk pr. innbygger (29) - oppnådde unntak fra denne regelen, likeledes Norge da EØS-avtalen ble inngått.

Salg av andre former for nikotinholdige produkter kan også reguleres, f.eks. nikotinholdige pastiller og tannpasta, som har vært solgt i USA. Slike produkter kan skape avhengighet, som igjen fører til at brukeren går over til sigaretter.

Andre tiltak kunne også vært trukket frem, og nye vil komme i tiden fremover. Av særlig interesse er aktiviteter som nå pågår i den amerikanske administrasjon (30). The Environmental Protection Agency avga i januar 1992 en rapport hvor det ble konkludert at tobakksrøyk i miljøet (environmental tobacco smoke) er et karsinogen for mennesker. I april 1994 foreslo Occupational Safety and Health Administration røykeforbud på de fleste offentlige steder og arbeidsplasser; lovregler om dette fikk tilslutning av en kongresskomite måneden etter. Under en kongresshøring i 1994 ble det "presented evidence" for at tobakksindustrien har manipulert nikotinkonsentrasjonen i tobakken i den hensikt å skape og vedlikeholde avhengighet hos røykere. Påstanden ble fremsatt av direktøren for Food and Drug Administration, som nå overveier å klassifisere sigaretter som et medikament. Hvis dette når frem, kan Food and Drug Administration bruke sin autoritet til en lang rekke lovtiltak for å redusere røykingen. Saken har møtt voldsom motstand fra tobakksindustrien.

Selv om det ikke kan betegnes som "tiltak", må denne oversikten også ta med de mange rettssaker hvor tobakksofre og deres etterlatte har reist erstatningkrav overfor tobakksindustrien. Slike saker pågår i flere land, og stor spenning er spesielt knyttet til den første kjennelsen fra den amerikanske høyesterett; 
hvis den går tobakksindustrien i mot, er det neppe tvil om at den vil utløse et ras av nye rettssaker som vil få enorme økonomiske konsekvenser for industrien.

\section{HVILKE TILTAK ER DE BESTE?}

Et nasjonalt program for tobakkskontroll inneholder gjerne en rekke ulike elementer, og det er vanskelig å kvantifisere virkningen av det enkelte tiltak. En WHO-konferanse i Madrid i 1988 anbefalte en strategi som omfatter de fleste av tiltakene nevnt ovenfor, men spesiell vekt ble lagt på avgiftsøkninger, reklameforbud og røykerestriksjoner (31).

Et annet barometer for virkningen av tiltakene er tobakksindustriens reaksjoner. Industriens strateger er de fremste eksperter, de vet bedre enn alle andre hvilke faktorer som har en uheldig innvirkning på salget av produktene. En god tommelfingerregel er derfor at når industrien opponerer, er tiltaket godt fra helsemessig synspunkt - og jo sterkere protestene er, dess bedre er tiltaket. Eller som uttrykt av WHO Expert Committee on Smoking Control (32):

" - experience in many countries has shown that the tobacco industry has invariable sought to reduce the impact of virtually all control measures, and, in general, does not willingly agree to any legislation or voluntary codes likely to have an adverse effect on tobacco sales. It would be surprising commercial practice if it did."

Industriens reaksjoner har vært særlig sterke overfor nettopp de tiltakene som ble vektlagt i den nevnte Madrid-konferansen.

Den optimale virkning av de tilgjengelige tiltak er trolig å servere dem som en samlet pakke, en "antitobacco cocktail" (31). I en slik sammenheng vil trolig de enkelte elementer ha en synergistisk virkning på hverandre.

\section{HVA KREVES FOR $̊$ Å SKAPE ET GODT FOREBYGGENDE PROGRAM?}

Etter å ha fulgt internasjonalt arbeid på dette feltet $\mathrm{i}$ de siste 25-30 årene, er jeg kommet til at følgende forutsetninger er nødvendige for å få god fremdrift i et land:

\section{(1) Solid faglig ekspertise}

Dvs. at det i landet finnes anerkjente epidemiologer, leger, jurister og andre sakkyndige med tilstrekkelig spisskompetanse på området, slik at de kan være gode premissleverandører for beslutningstakerne.

Ekspertene bør også være pådrivere for å få tiltakene gjennomført. Ikke alle fagfolk vil være enig i dette; de trives best i den tilbakelente rollen bak skrivebordene; "politikken og propagandaen får andre stelle med", har jeg hørt si. I denne sammenheng kan det være på sin plass å minne om den visitt som vinneren av Nobels fredspris 1995, professor Joseph Rotblat, avla forskerne i sitt Nobelforedrag (33).

"You are doing fundamental work, pushing forward the frontiers of knowledge, but often you do it without giving much thought to the impact of your work on society. Percepts such as 'science is neutral' or 'science has nothing to do with politics', still prevail. They are remnants of the ivory tower mentality, although the ivory tower was finally demolished by the Hiroshima bomb."

Men det finnes store vitenskapsmenn som har hatt et annet syn; professorene Richard Doll og Richard Peto har deltatt aktivt både nasjonalt og internasjonalt for å få myndighetene til å aksjonere i tobakksaken.

\section{(2) Sterke pressgrupper}

Over alt i verden ser vi at det er de frivillige organisasjoner som gjennom intens lobbyvirksomhet har båret arbeidet frem, i første rekke foreningene som arbeider med kreft, hjerte- og lungesykdommer, foruten grupper som arbeider for røykfrie miljøer.

Fagforeninger for helsepersonell, spesielt legeforeningene, har vært viktige støttespillere. I USA har legeforeningen nylig tatt bladet fra munnen. JAMA bruker et helt nummer (19.juli 1995) på en serie artikler om tobakksindustriens kyniske virksomhet. Lederartikkelen (34) er signert av hele toppsjiktet i American Medical Association, og her heter det:
"We think that these documents ... provide massive, detailed and damning evidence of the tactics of the tobacco industry. They show us how the industry has managed to spread confusion by suppressing, manipulating, and distorting the scientific record. They also make clear how the tobacco industry has been able to avoid paying a penny in damages and how it has been able to remain hugely profitable from the sale of a substance known by scientists to be lethal."

Få uker etterpå lanserte President Clinton et nytt handlingsprogram mot tobakk.

Også Den norske lægeforening har deltatt aktivt som pressgruppe, mest kjent er vel landsstyrets henstilling til regjeringen om å gjøre Norge røykfritt (35). Så tidlig som i 1967 hadde Den norske lægeforenings kreftkomite en utredning om saken (36).

\section{(3) Engasjerte byråkrater}

Embetsmennene i helsedepartementene og finansdepartementene spiller en sentral rolle; de legger opp sakene for politikerne, slik at de kan få den nødvendige tilslutning. 
Det er neppe tvil om at saken kan bli forsinket når byråkratene ikke finner den presserende nok i forhold til tallrike andre oppgaver. Men det er heller ikke tvil om at det er kommet virkelig fart på prosessen når saken har møtt hel-tente byråkrater, som har lagt den øverst i bunken og gjort sitt ytterste for å bistå ministrene med å finne utveier til å drive den gjennom.

\section{(4) Handlekraftige politikere}

I siste instans er det politikerne det hele henger på. All fremdrift stanser hvis ikke helseministrene bryr seg om saken, og hvis de ikke har en såpass sterk posisjon i regjeringskollegiet at de får statsministrene og de andre statsrådene med. Regjeringene må også ha evne og myndighet til å sikre flertall i parlamentene.

Historien er full av eksempler på likeglade politikere som ikke har brydd seg, men begrenset sin aktivitet til det minimum som er nødvendig for å gi skinn av at de er "deeply concerned". Mange har latt seg overtale av tobakksindustrien til frivillige avtaler som sikrer industrien fortsatt fritt spillerom; ja, det var endog en statsminister som etter endt tjeneste lot seg verve - for et klekkelig honorar - av Philip Morris til å bistå firmaet i deres markedsføring i ØstEuropa og i de fattige landene (37).

Men vi har også sett andre politikere som virkelig har tatt et tak. Hos oss var det Egil Aarvik som i 1969 la frem handlingsprogrammet med bl.a. reklameforbudet, og Tove Strand Gerhardsen som i 1988 greidde å få "Røykeloven" gjennom. Selv har jeg hørt en utenlandsk helseminister si at han var villig til endog å ofre sitt politiske liv for saken. Vi har da også vært vitne til at engasjerte politikere har fått ødelagt sin politiske karriere, iallfall midlertidig, pga. sitt engasjement (38). I den senere tid har vi imidlertid lagt merke til at handlekraftig aksjon har gitt politisk gevinst, og at politikerne begynner å få øynene opp for dette faktum.

Etter mitt skjønn vil en få den raskeste fremdrift i dette forebyggende arbeid hvis alle disse fire instanser er med for fullt; mangler ett ledd, blir prosessen straks forsinket. Det er dessverre ikke til å komme forbi at hvis saken underveis må behandles av personer som selv er røykere, har den tendens til å stoppe opp. Det er menneskelig, men beklagelig.

For alle ledd er det vesentlig at en ikke gir seg inn på å kompromisse med de økonomiske interessene, eller som uttrykt av World Health Expert Committee on Smoking Control (32):

"- no worthwhile progress can be achieved unless governments are prepared to put the interests of public health before those of private tobacco enterprise, and to secure appropriate action by state-owned industry."

\section{CANADA - FLINKEST I KLASSEN}

For tiden er det Canada som er nådd lengst $\mathrm{i}$ å utnytte det tilgjengelige arsenal av tiltak. Uten tvil har dette sammenheng med at man her hadde helklaff: alle de ovennevnte fire instanser var topp engasjert $\mathrm{i}$ å få til et effektivt program.

I tillegg til et intelligent og omfattende opplysningsarbeid, fikk landet i 1988 en radikal tobakkslovgivning (39) - med totalt reklameforbud (som også setter bom for snikreklame), sterke helseadvarsler (som fra 1994 på alle punkter fyller de tidligere omtalte kravene til effektiv merking (40)), og røykfrie offentlige lokaler. Myndighetene innførte også store avgiftsøkninger.

Arbeidet har imidlertid hatt alvorlige tilbakeslag. I 1994 senket myndighetene avgiftene igjen pga. økt smugling. Dette ble fulgt av 7\% økning av tobakksforbruket og en økning i røykeprevalensen hos ungdom - etter at det $\mathrm{i}$ tidligere år hadde vært et jevnt fall (41). Og 21. september 1995 kom det store sjokket: Tobakksindustrien fikk medhold i den kanadiske høyesterett om at tobakksloven fra 1988 var i strid med grunnlovens bestemmelser om ytringsfrihet (vedtatt av 5 mot 4 dommere). Dommen har reist sterke reaksjoner i media, som i denne saken står på helsemyndighetenes side. Kommentatorene har uttrykt bekymring over at denne saken forrykker maktbalansen fra parlamentet til rettssalene (42).

Men myndighetene var ikke nede for telling engang. Allerede den 11. desember 1995 kunngjorde helseminister Diane Marleau at hun våren 1996 vil fremme et lovforslag som tetter igjen de lovtekniske smutthull som tobakksindustrien hadde funnet. Den nye loven vil dertil bli enda mer radikal i sitt innhold enn den forrige (43).

\section{HVA MED NORGE?}

Vi var tidlig på banen. Først ute var de frivillige organisasjonene, som startet opplysningsvirksomhet og senere stadig har økt sin innsats.

Allerede i februar 1964 kom helsedirektøren med en redegjørelse (44), bare en måned etter den velkjente første rapporten fra hans amerikanske kollega - the US Surgeon General (45). Samtidig tok Kjell Bondevik saken opp i en interpellasjon i Stortinget, som vedtok at det måtte nedsettes en komite for å planlegge kampen mot den skadelige røykingen. Helsedirektøren tok initiativet til at det i 1965 ble oppnevnt et tverrfaglig utvalg ("Utvalget for forskning i røykevaner"), som ble administrert av Landsforeningen mot Kreft. I 1967 kom utvalgets rapport ("Påvirkning av røykeatferd") (46), som anbefalte et koordinert program med opplysnings- og avvenningstiltak, og restriktive virkemidler, bl.a. et 
totalt reklameforbud. Et nytt statlig organ ble foreslått som koordinator av programmet.

Norge var det første land i verden hvor et tverrfaglig utvalg la frem et slikt handlingsprogram. Rapporten ble kjent i utlandet, og i 1969 ble den utgitt på engelsk av Den internasjonale kreftunion (UICC) (47).

Nå fulgte begivenhetene i rask rekkefølge (48):

1969: Regjeringen legger fram en stortingsmelding om saken, og fremmer i hovedtrekkene forslagene fra Utvalget for forskning i røykevaner (St.meld. nr. 62 (1968-69)).

1970: Stortingets sosialkomite slutter seg enstemmig til forslagene i Stortingsmeldingen, og skjerper den endog noe (Innst. S. nr. 143 (1969-70). En lovkomite (formann: professor Anders Bratholm, sekretær: stud.jur. - senere professor Asbjørn Kjønstad) nedsettes for å lage utkast til tobakkslov.

1971: Innstillingen fra lovkomiteen blir fremlagt (49). Statens tobakkskaderåd opprettes ved Kgl.res. av 4. juni.

1972: Regjeringen fremmer proposisjon om tobakkslov (Ot.prp. nr. 3 (1972-73)).

1973: Stortinget vedtar Tobakksloven, og forsterker den noe $\mathrm{i}$ forhold til Regjeringens forslag (Innst. O. nr. 25 (1972-73)) ${ }^{*}$.

1974: Statens tobakkskaderåd får eget sekretariat med fast ansatt personell og med eget kapittel i statsbudsjettet. Sosialdepartementet utferdiger forskrifter til Tobakksloven.

1975: Tobakksloven trer i kraft pr. 1. juli, med bl.a. totalt reklameforbud og helseadvarsler på tobakkspakkene.

1984: Sosialdepartementet fastsetter nytt system for helseadvarslene med 12 forskjellige tekster (Rundskriv IK-1994, Tillegg 4, Helsedirektoratet).

1987: Regjeringen fremmer proposisjon om tillegg til Tobakksloven, med bestemmelser om røykfrihet på offentlig sted og på arbeidsplassene ("Røykeloven") (Ot.prp. nr. 27 (1987-88)).

1988: Stortinget vedtar "Røykeloven" (Innst. O. $n r$. 48 (1987-88)).

1989: Sosialdepartementets arbeidsgruppe for røykfritt Norge i år 2000 blir opprettet ${ }^{* *}$. Det kommer en Kgl. res. av 13/10 om forbud mot nye nikotinprodukter (Rundskriv IK-2323, Helsedirektoratet).

\footnotetext{
* Bratholmkomiteen hadde inkludert i lovforslaget bestemmelsene i en gammel lov fra 1899 som ga kommunene adgang til å forby salg av tobakk til personer som ikke har fylt 15 år. Stortinget hevet aldersgrensen til 16 år.

Gruppen ble avviklet i 1994. I 1995 etablerte medlemmene - med unntak av de statlige - en ny gruppe under navnet "Tobakksfritt".
}

1993: Sosial- og helsedepartementet strammer til forskriftene i "Røykeloven" (Rundskriv I-18/93).

1994: Regjeringen fremmer proposisjon om endringer i Tobakksloven: Reklameforbudet skjerpes for å hindre snikreklame, røykerestriksjonene blir strengere, alders grense for salg heves til 18 år, sigarettautomatene forbys (Ot.prp. nr. 69 (1993-94)).

1995: Stortinget vedtar endringene i Tobakksloven (Innst. O.nr. 26 (1994-95), og departementet utarbeider forskrifter (Rundskriv I-47/95).

1996: Endringene i Tobakksloven trer i kraft pr. 1. januar.

Fram til 1975 ble det holdt et rimelig høyt tempo i utviklingen, og det er ingen tvil om at Norge på denne tiden var blant foregangslandene, vi var f.eks. blant de aller første med et totalt reklameforbud.

Oversikten viser imidlertid at aktivitetsnivået dabbet av i de påfølgende år, og ledertrøyen ble etter hvert overtatt av andre, bl.a var det nye land som var først ute med røykerestriksjoner på offentlig sted. Riktignok pågikk det $\mathrm{i}$ denne tiden en omfattende opplysningsvirksomhet i statlig regi, med distribusjon av opplysningsmateriell, kurs for feltarbeidere, sommerkampanjer på campingplasser m.v., og med store annonser i aviser og ukeblad. Annonsene ble mulige p.g.a. store tilskudd fra Statens informasjonstjeneste, men etter hvert tørket denne finansieringskilden ut, samtidig som Tobakkskaderådets eget opplysningsbudsjett ble holdt uendret på et lavt nivå.

Fra 1980 til 1982 hadde vi tre sterke avgiftsøkninger som ga prisøkninger på henholdsvis 29, 22 og 10\% (38), og som ble fremmet med en helsemessig begrunnelse. P.g.a. engstelse for handelslekkasje til Sverige har avgiftsøkninger av denne størrelsesorden ikke vært forsøkt senere. Etter min oppfatning er dette en sak som burde egne seg for behandling i Nordisk Råd, slik at landene kunne samordne seg i å utnytte det sterkeste virkemiddel i tobakkskampen. Norge burde dessuten øke avgiften selektivt på rulletobakk, som har et oppsiktsvekkende høyt innhold av tjære og nikotin (50), og som særlig brukes av sosialgrupper med det høyeste tobakksforbruk.

Et beklagelig tilbakeslag kom i tilknytning til EØS-avtalen, som forpliktet Norge på EUs rådsdirektiver om helseadvarsler. EU-reglene er først og fremst utformet for å motvirke at ulike nasjonale bestemmelser skal "...skape handelshindringer og dermed vanskeliggjøre det indre markeds opprettelse og funksjon" (Rådsdirektiv 92/41/EØF). Først etter dette heter det: "Slike regler må ta tilbørlig hensyn til vern av folkehelsen ...".

EU-reglene har ført til en svekkelse av det system vi hadde, både når det gjelder design og areal på pakkene. Under EØS-forhandlingene krevde ikke Norge unntak fra direktivet, derimot krevde vi - og fikk - unntak fra EU-reglenes forbud mot salg av 


\section{ANTALL DØDE 1988 av tobakksbruk og enkelte andre årsaker BEVILGNINGER 1992
til forebygging, sosialdept., $1000 \mathrm{kr}$.}
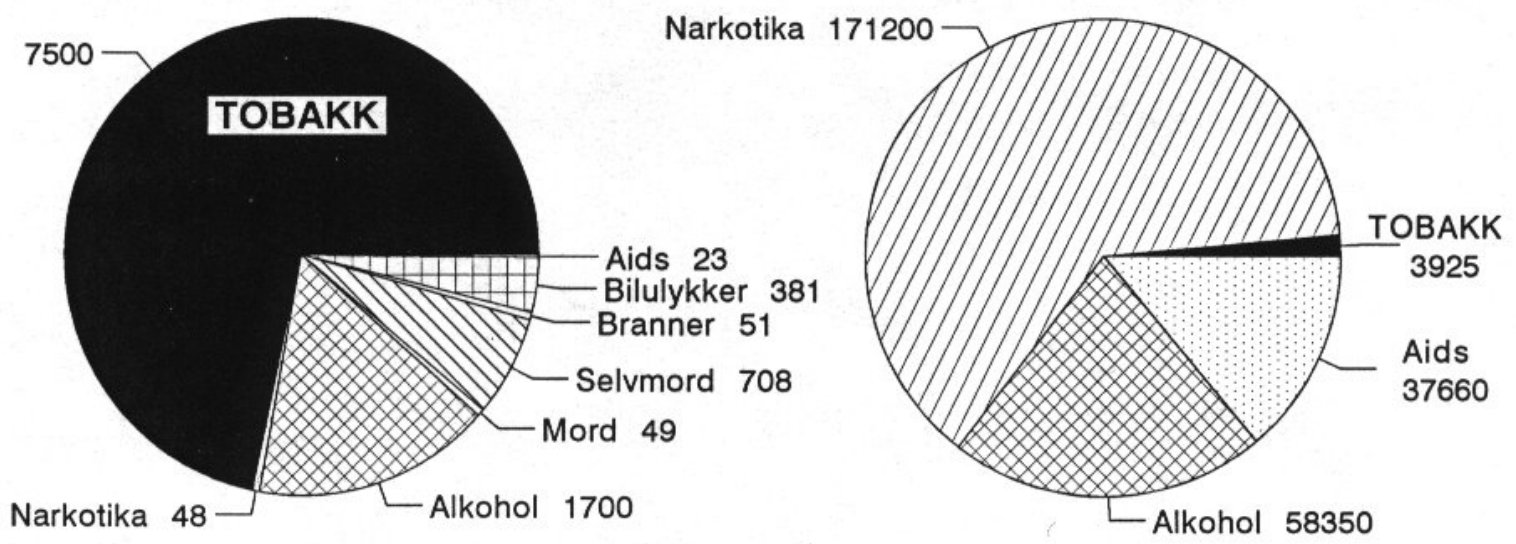

Figur 1. Utfordringer og innsats. Kilder: Sanner (61), Fekjær (62), Statistisk sentralbyrå (63), Budsjettproposisjonen for 1992 (64), personlige meddelelser fra Statens institutt for folkehelse og Statens institutt for alkohol- og narkotikaforskning.

Det er en rekke forbehold knyttet til figuren. Dette er redegjort for i eget notat, tilgjengelig fra forfatteren. Hensikten med figuren er hovedsaklig å peke at det for en del satsningsområder er et misforhold mellom problemets størrelse og de statlige bevilgninger til tiltak mot problemet.

tobakk til oralt bruk. Konsekvensene ble at tobakksindustrien fikk både i pose og sekk: Det norske merkesystemet ble svekket og det norske snusmarkedet ble berget. Fra helsevern-synspunkt ville et unntak fra merkebestemmelsene vært å foretrekke, og at vi heller hadde akseptert snusforbudet. Det vil nå bli meget vanskelig å få unntak fra merkebestemmelsene, slik at vi kan legge oss på Canadas regler, og det vil trolig bli umulig å nå frem til et system med "plain packaging".

I de siste årene er det imidlertid kommet en ny giv i det statlige engasjement, og spesielt skal nevnes at sosialkomiteen avga en meget positiv innstilling til den siste endringen $\mathrm{i}$ Tobakksloven. Innstillingen inneholdt bl.a en figur fra et foredrag som jeg holdt $\mathrm{i}$ et av komiteens møter (Figur 1). Komiteens budskap til Regjeringen var tydelig: Mer penger til tobakksarbeidet! Og i budsjettproposisjonen for 1996 kom det en markert økning i bevilgningene til Statens tobakkskaderåd, både til stillinger og drift. Under høstens budsjettbehandling plusset Sosialkomiteen endog på 5 millioner kroner til opplysningsarbeidet (Budsjettinnstilling S. nr. 11 (1995-96) kap. 714). La oss håpe at denne utviklingen fortsetter i økende takt.

\section{HVA HAR VI SÅ OPPNÅDD?}

Figur 2 viser registrert salg av sigaretter og røyketobakk pr. innbygger 15 år og over i perioden 195094. Vi hadde en sterk økning fram til midten av 70årene (høyeste tall ble registrert i 1974/75). Senere har vi hatt en nedgang. Det registrerte salget er målt i gram tobakk, og vekten av tobakken i én sigarett er satt til 1 gram, slik det var tidligere. Gjennom årene har det pågått en viss reduksjon av tobakksvekten pr. sigarett, noe som vil gi lavere forbruk enn det figuren viser. På den annen side har vi hatt et økende kjøp av varer tax-free og på handleturer til Sverige, noe som vil gi høyere forbrukstall (51). Trolig gir utviklingen av det registrerte salget et bilde som ikke avviker vesentlig fra det faktiske forbruket, og det kan ikke være tvil om at det fra 1970-årene er kommet en ny trend $\mathrm{i}$ forbruksutviklingen. Hvis salget hadde fortsatt å øke i samme tempo som i 1950-70, ville vi i dag hatt et salg som hadde vært ca. $65 \%$ høyere enn det er. Og enda ville vi ikke ha nådd opp til f.eks Storbritannia, USA og Canada, hvor salgskurven kulminerte på et nivå som var over dobbelt så høyt som vårt topp-punkt. I disse landene er også lungekreftdødeligheten betydelig høyere enn hos oss $(32,38)$. Den nye trenden i Norge indikerer at vi allerede har oppnådd en betydelig helsegevinst.

Figur 3 viser resultat av landsomfattende undersøkelser av norske skolebarns røykevaner, 7.-9. klasse. Frem til 1975 hadde vi en dramatisk økning i røykeprosenten, særlig blant jentene. Senere har vi hatt en nedgang. Vi mangler dessverre målinger $\mathrm{i}$ tiden mellom 1963 og 1975, og dermed er det usikkert hvilket år toppen ble nådd. Statens institutt for alkoholforskning har imidlertid foretatt målinger blant ungdom 15-21 år i Oslo (fra 1970) og Bergen (fra 1973). Høyeste røykeprosenter ble registrert i Oslo i 1974 (52), og i Bergen i 1975 (53), fulgt av en 


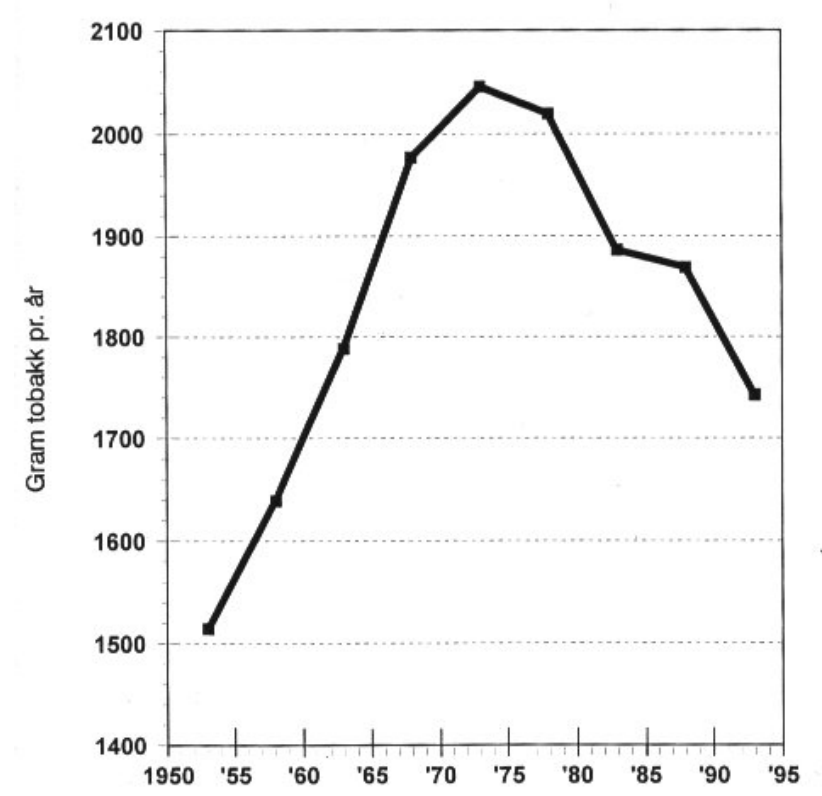

Figur 2. Salg av sigaretter og røyketobakk pr. innbygger 15 år og over, Norge 1950/51 - 1994/95. Gjennomsnittstall for femårs-perioder. Kilde: Meldinger fra Toll- og avgiftsdirektoratet/Statens tobakkskaderåd. Ved beregningene er vekten av 1 sigarett satt lik 1 gram.

nedadgående tendens, og det er neppe tvil om at røykeprosenten for norske skolebarn nådde et toppnivå i midten av 1970-årene.

Figur 4 viser prosent dagligrøykere blant voksne. For menn er det gjennomgående synkende tall, i alder 45-64 år er prevalensen gått ned med nær 20 prosentpoeng. Den svakeste nedgang hadde vi i begynnelsen av 1980-årene, noe som rimer med det forholdsvis lave aktivitetsnivå i disse årene. For kvinner er det liten endring å spore, bortsett fra yngste aldersgruppe, hvor nedgangen er like sterk som hos menn. For middelaldrende og eldre kvinner må vi ta hensyn til en klar kohorteffekt, som beskrevet av Rønneberg og medarbeidere (54). Tidligere var det lite røyking i disse aldersgrupper; etter krigen fikk vi en sterk økning i røyking blant unge kvinner, som tok med seg sine røykevaner etter hvert som de ble eldre. I de enkelte kvinnekohorter er det imidlertid kommet en tydelig nedgang i røykeprosenten $(51,54)$.

Statens helseundersøkelsers kartlegginger av 4042-åringer har inntil 1994 vist en svak nedgang i røykeprosenten hos menn, mens den hos kvinner har vært stillestående eller svakt økende. I de tre fylkene som ble undersøkt i 1994-95 (Nordland, Rogaland, AustAgder) er det imidlertid kommet en nedgang på 5 prosentpoeng hos menn, og på 3 prosentpoeng hos kvinner, sammenholdt med resultatene tre år forut (55).

Det er betydelige forskjeller i utviklingen mellom ulike sosialgrupper; personer med høy utdanning har et gunstigere forløp enn personer med lav utdanning

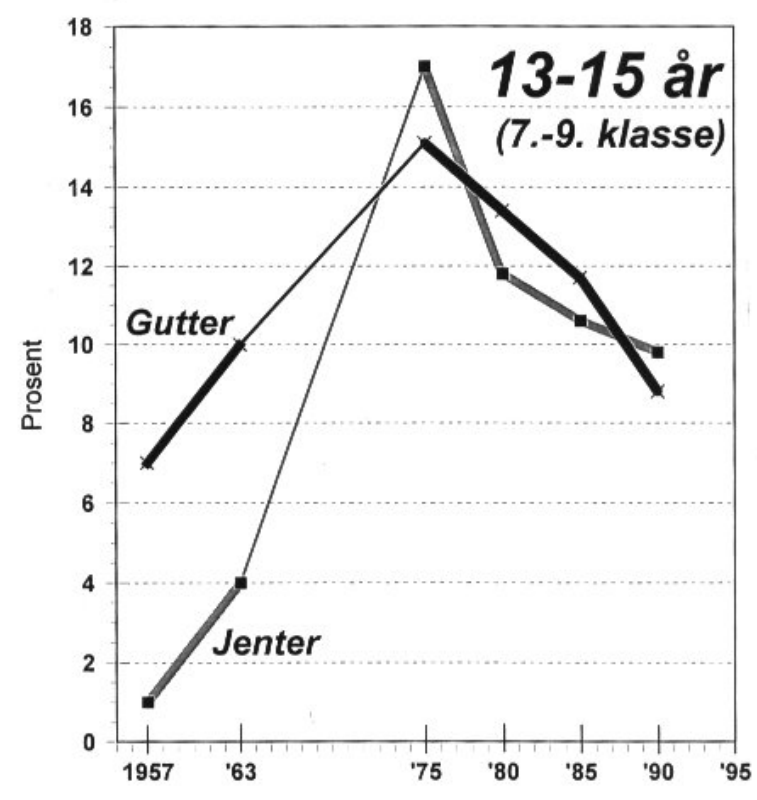

Figur 3. Prosent dagligrøykere blant elever i 7.-9. klasse i grunnskolen, Norge. Resultat av landsomfattende røykevaneundersøkelser utført av Landsforeningen mot Kreft $(65,66)$ i 1957 og 1963, og av Statens tobakkskaderåd i $1975,-80,-85$ og -90 (kilde: ref $(51,67)$ og personlige meddelelser). Antall elever som inngår i hver av undersøkelsene varierer mellom 2000 og 3000 (hvert kjønn); i 1963 noe mindre.

(56,57). Hos 25-34-åringer med grunnskole som høyeste utdannelse har røykeprosenten i over 20 år ligget ganske fast på noe under 60\% (Terje Svendsen, Statens tobakkskaderåd, personlig meddelelse). Nå må vi huske på at denne befolkningsgruppen er redusert fra nær $40 \%$ til under $10 \%$ i disse årene (Statistisk sentralbyrå, personlig meddelelse); dvs. at antall røykere med bare grunnskole er gått ned til under en fjerdedel i denne tiden .

Når det gjelder røykeprevalensen i ulike geografiske områder, finner vi også store forskjeller - med høyeste verdier i Finnmark og laveste i Rogaland for 40-42-åringer (55). For middelaldrende menn i Oslo/Akershus har nedgangen i røykingen vært relativt sterk (58).

Hva så med utviklingen av tobakksykdommene, f.eks. lungekreft? Den positive utviklingen i røykevanene blant menn har pågått såvidt lenge at vi snart skulle vente at insidensøkningen stopper opp og viser tegn til nedgang, spesielt i Oslo/Akershus. Kreftregisterets fremskrivning av lungekreftinsidensen varsler at dette er $\mathrm{i}$ ferd med å skje for menn, og for Oslo er de aldersjusterte insidensrater for 1988-92 lavere enn for 1983-87. For kvinner derimot, regnes det med fortsatt økning i årene fremover (59). Med spenning ser vi frem til nye rapporter fra Kreftregisteret.

Sammenfatningsvis kan det sies at vi tidligere hadde en sterk økning i røykingen, men at det siden 1970-årene er kommet en nedgang. Det er liten grunn 

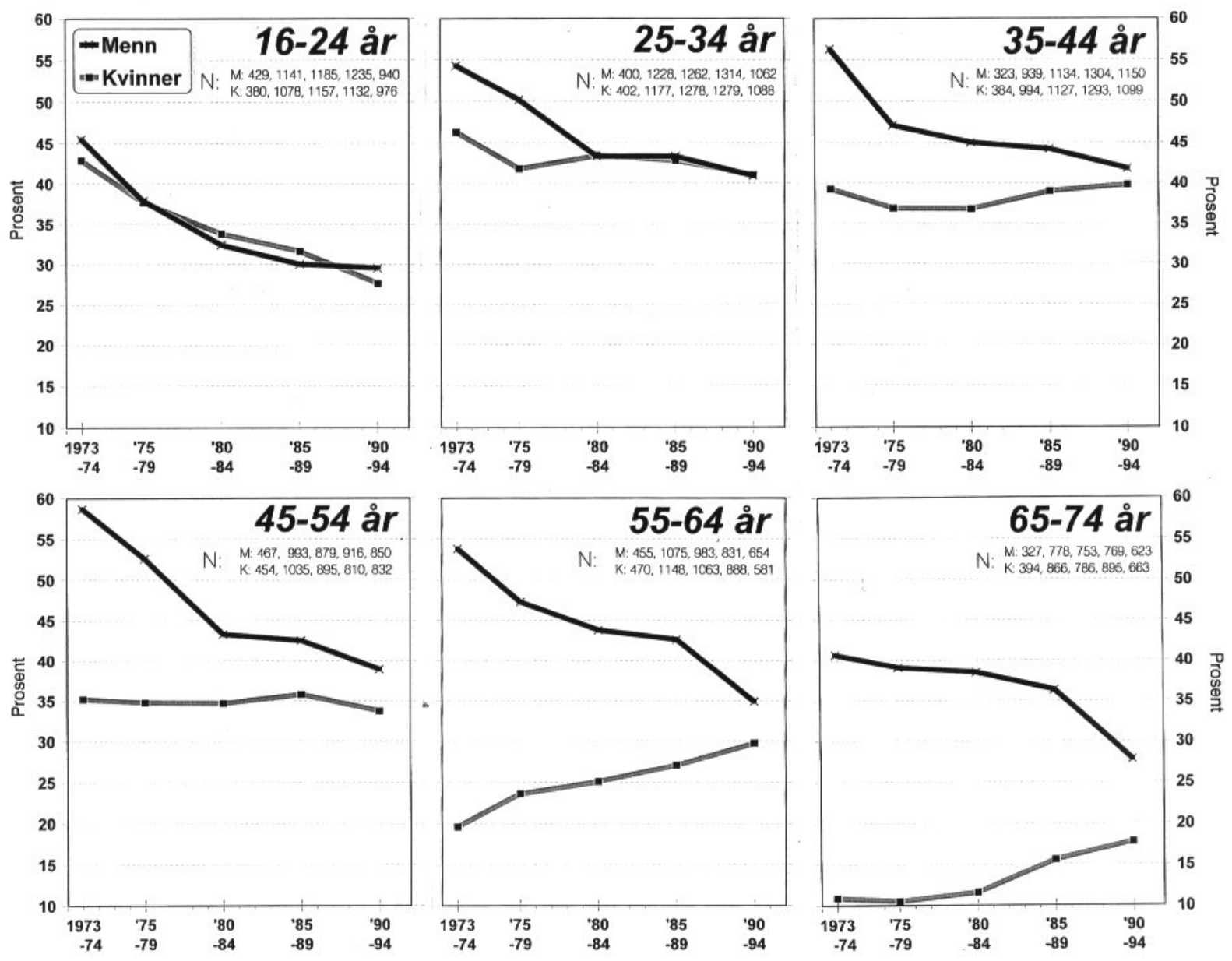

Figur 4. Prosent dagligrøykere etter kjønn og alder (16-74 år), Norge 1973-94. Resultat av Statistisk sentralbyrå/ Statens tobakkskaderåds årlige undersøkelser i representative utvalg av den voksne norske befolkning; undersøkelsene har pågått siden 1973. Gjennomsnitt for 1973/74, 1975-79, 1980-84, 1985-89 og 1990-94. Antall personer intervjuet $\mathrm{i}$ de nevnte perioder er gitt øverst til høyre i figurene for hver aldersgruppe. Kilde: Statens tobakkskaderåd ved Terje Svendsen, personlig meddelelse.

til å mene at denne utviklingen er kommet av seg selv - det var langt igjen før markedet hadde nådd et metningspunkt. Nedgangen må kunne føres tilbake til den samlede innsats som offentlige myndigheter, frivillige organisasjoner og enkeltmennesker har stått for i disse årene. Fallet er ikke så sterkt som vi skulle ønske - men vi må huske på at vi har å gjøre med et avhengighetsskapende stoff. Hvis nå kreftene samles til en langt sterkere innsats, bør vi oppnå enda bedre resultater.

\section{DEN GLOBALE UTFORDRING}

Mest bekymringsfull er imidlertid utviklingen i de fattige landene. Som nevnt innledningsvis: Denne saken er et globalt anliggende som burde tas opp på høyeste plan i FN - med sikte på en radikal og sterkt handlingsrettet konvensjon.

Er dette utopi? Nei, ikke helt. I mai 1995 ble det fattet en resolusjon under 48. World Health Assembly, som ba generaldirektøren om å fremlegge en rapport om "..the feasibility of developing an international instrument such as guidelines, a declaration, or an International Convention on Tobacco Control to be adopted by the United Nations .." (60).

Skal dette lykkes, må saken drives frem av enkeltland som har visjonene i orden.

Norske politikere har i de siste årene høstet stor anerkjennelse for sin innsats $i$ fredsarbeidet. Kunne den globale kamp mot tobakkskadene være en ny utfordring? Norge har politikere av internasjonalt format, endog med faglig innsikt i saken. Og de har for hånden et godt faglig og administrativt støtteapparat.

I denne sammenheng har også norske epidemiologer en stor utfordring.

Stor takk til Terje Svendsen, Statens tobakkskaderåd, som har fremskaffet tallmateriale for figurene 2-4. Forfatteren har også fått verdifull informasjon fra Arne Hauknes, Øystein Krüger, Karl Erik Lund, Garfield Mahood, Tore Sanner og David Simpson. 


\section{LITTERATUR}

1. Peto R. Smoking and death: the past 40 years and the next 40. BMJ 1994; 309: 937-9.

2. Doll R, Hill AB. Smoking and carcinoma of the lung. BMJ 1950; ii: 739-48.

3. Doll R, Hill AB. The mortality of doctors in relation to their smoking habits. A preliminary report. BMJ 1954; i: 1451-5.

4. Doll R, Hill AB. Lung cancer and other causes of death in relation to smoking. A second report on the mortality of British doctors. BMJ 1956; ii: 1071-6.

5. Doll R, Peto R. Mortality in relation to smoking: 20 years' observation on male British doctors. BMJ 1976; ii: 1525-36.

6. Doll R, Peto R, Wheatley K, Gray R, Sutherland I. Mortality in relation to smoking: 40 years' observation on male British doctors. BMJ 1994; 309: 901-11.

7. Kreyberg L. Aetiology of lung cancer. A morphological, epidemiological and experimental analysis. Oslo: Universitetsforlaget, 1969.

8. Peto R, Lopez AD, Boreham J, Thun M, Heath C Jr. Mortality from smoking in developed countries 1950-2000: indirect estimates from national vital statistics. Oxford: Oxford University Press, 1994.

9. Smoking and its effect on health. WHO Technical Report Series No. 568. Genève: World Health Organization, 1975.

10. Written question from the European Parliament. European Bureau for Action on Smoking and Health (BASP), Brussels 1994; Newsletter No. 25: 7.

11. The health consequences of smoking: Nicotine addiction. A report of the Surgeon General, 1988. DHHS Publication No. (CDC) 88-8406. Rockville: U.S. Department of Health and Human Services, Public Health Service, 1988.

12. Jøsendal O, Aarø LE. Skolebasert forebygging av røyking blant ungdom. Nor J Epidemiol 1995, 5: 161-170.

13. Aarø LE. Tobakksavgift og finansiering av forebyggende og helsefremmende tiltak. Oslo: Samarbeidsorganet for helsefremmende oppgaver (SOHO), 1995.

14. Effect of tobacco advertising on tobacco consumption. A discussion document reviewing the evidence (the Smee Report). London: Department of Health, Economics and Research Division, 1992.

15. Ramström LM. Summary of the NTS study on the Swedish tobacco labelling system. Stockholm: National Smoking and Health Association, 1979.

16. The labelling of tobacco products in the European Union. Brussels: European Bureau for Action on Smoking Prevention, 1993.

17. Tobacco health warning messages, inserts and toxic constituent information study. Final report. Toronto: Tandemar Research Inc., 1992.

18. Plain packs would keep kids off tobacco market. Toronto: IndoorAir, Non-smokers' Rights Association, June 1995: 3.

19. Tobacco price and the smoking epidemic. Smoke-free Europe: 9. Copenhagen: European Office of the World Health Organization, Public Information Office, 1987.

20. Lund KE. Tobakkens pris. Oslo: Statens tobakkskaderåd, 1989.

21. Pekurinen M. Economic aspects of smoking. Is there a case for government intervention in Finland? Research reports 16/91. Helsinki: National Agency for Welfare and Health, 1991.

22. MacKenzie TD, Bartecchi CE, Schrier RW. The human costs of tobacco use (Second of two parts). N Engl J Med 1994; 330: 975-80. 
23. Effects of excise taxes on smoking and health. In: Reducing the health consequenses of smoking: Twenty-five year of progress. A report of the US Surgeon General. DHHS Publication No (CDC) 89-8411. Rockville: US Department of Health and Human Services, Public Health Service, 1989: 529-39.

24. Townsend J, Roderick P, Cooper J. Cigarette smoking by socioeconomic group, sex and age: effects of price, income and health publicity. BMJ 1994; 309: 923-7.

25. Opp i røyk? Om tobakksforbruk i Norge gjennom 20 år 1973-93. Oslo: Statens tobakkskaderåd, 1994.

26. Wakefield MA, Wilson D, Owen N, Esterman A, Roberts L. Workplace smoking restrictions, occupational status, and reduced cigarette consumption. J Occup Med 1992; 34: 693-97.

27. Jason LA, Ji PY, Anes MD, Birkhead SH. Active enforcement of cigarette control laws in the prevention of cigarette sales to minors. JAMA 1991; 266: 3159-61.

28. Parish S, Collins R, Peto R, Youngman L, Barton J, Jayne K, et al. Cigarette smoking, tar yields, and non-fatal myocardial infarction: 14000 cases and 32000 controls in the United Kingdom. BMJ 1995; 311: 471-7.

29. Lund KE. Bruk av snus i Norge. I: Tobakkskaderådets "store brune". Oslo: Statens tobakkskaderåd, 1990: 15-44.

30. Davis RM. Slowing the march of the Marlboro man. Unless current smoking pattern change cigarettes will kill 10 million people a year by 2025. BMJ 1994; 309: 889-90.

31. It can be done. A smoke-free Europe. Report of the first European Conference on Tobacco Policy, Madrid 7-11 November 1988. Copenhagen: WHO Regional Publications, European Series, No. 30, 1990.

32. Controlling the smoking epidemic. Report of the WHO Expert Committee on Smoking Control. WHO Technical Report Series 636. Genève: World Health Organization, 1979.

33. The Nobel Lecture given by The Nobel Peace Prize Laureate 1995 Joseph Rotblat. Oslo: Den norske Nobelkomite, 1995.

34. The Brown and Williamson Documents. Where do we go from here? Editorial. JAMA 1995; 274: 256-58.

35. Den norske lægeforenings landsstyre, Sarpsborg 13/6.1981. Sak 20: Avvikling av import og omsetning av tobakksvarer i Norge. Tidsskr Nor Laegeforen 1980; 101, No. 31B: 150-2.

36. Tobakkrøking og helse. Innstilling av 21. februar 1967 fra Den norske lægeforenings kreftkomité. Tidsskr Nor Lageforen 1967; 87: 1007-13.

37. Rufford N, Leppard D, Burrell I. Thatcher gets \$ $1 \mathrm{~m}$ job with top US tobacco firm. Sunday Times 19.7.1992: 1,3.

38. Bjartveit K. Legislation and political activity. In: Forbes WF, Frecker WF, Nostbakken D, ed. Proceedings of the Fifth World Conference on Smoking and Health, Winnipeg, Canada, 1983, 1: 31-45. Ottawa: Canadian Council on Smoking and Health, 1983.

39. Government of Canada. The Canadian Tobacco Products Control Act. Ottawa: Statute of Canada, 35-36-37, Elisabeth II, 1988: 393-405.

40. Kaiserman MJ. The effectiveness of health warning messages. Tobacco Control 1993; 2: 267-269.

41. Stephens T. Workshop report: Trends in prevalence of smoking. Chronic Diseases in Canada 1995; 15, No. 1:27-32.

42. Goodyear M. Tobacco Products Control Act (Canada). Genève: International Union Against Cancer, GlobaLink, 25 september 1995.

43. Health Canada. Tobacco Control. A Blueprint to protect the health of the Canadians. Ottawa: Health Canada, 1995.

44. Sigarettrøyking og helse. En redegjørelse fra helsedirektøren. Tidsskr Nor Lageforen 1964; 84: $300-4$. 
45. Smoking and Health. Report of the Advisory Committee to the Surgeon General of the Public Health Service. PHS Publication No. 1103. Washington, D.C.: Department of Health, Education and Welfare, Public Health Service, 1964.

46. St.meld. nr. 62 (1968-69) Om påvirkning av røykevaner. (Denne stortingsmeldingen inneholder som vedlegg rapporten fra Utvalget for forskning i røykevaner, s. 15-139.)

47. Influencing smoking behaviour. UICC Technical Report Series Vol 3. Genève: International Union Against Cancer, 1969.

48. Bjartveit K. Røyking og helse - situasjonen i dag. I: Larsen $Ø$, red. Forebyggende medisin. Oslo: Universitetsforlaget, 1975: 55-66.

49. Innstilling til lov om restriktive tiltak ved omsetning av tobakksvarer m.v. (Tobakksloven). Fra en komité oppnevnt ved kongelig resolusjon av 41. juli 1970. Oslo: Sosialdepartementet, 1970.

50. Hauknes A. Målinger av giftstoffer i rulletobakken. Oslo: Statens tobakkskaderåd, 1994.

51. Bjartveit K. Fifteen years of comprehensive legislation: results and conclusions. In: Durston B, Jamrozik K, ed. The global war. Proceedings of the Seventh World Conference on Tobacco and Health, 1st-5th April 1990, Perth, Western Australia. Perth: Health Department of Western Australia, 1990: 71-80.

52. Irgens-Jensen O, Rud MG. Bruk av stoffer, alkohol og tobakk blant gutter og jenter: Oslo 19681976. Oslo: Universitetsforlaget, 1979.

53. Irgens-Jensen. Bergens-ungdommens bruk av stoffer, alkohol og tobakk 1971-79. Oslo: Statens institutt for alkoholforskning, 1980.

54. Rønneberg A, Lund KE, Hafstad A. Lifetime smoking habits among Norwegian men and women born between 1890 and 1974. Int J Epidemiol 1994; 23: 267-76.

55. Hjertesaken. Rapporter fra Statens helseundersøkelser, Oslo 1974-

56. Bjartveit K, Lund KE. Røykeepidemiologi. I: Bjartveit K, red. Håndbok for hjerte-karundersøkelsen. Oslo: Statens helseundersøkelser, 1987: 37-45.

57. Lund KE. Er røyking blitt lavstatus? Samfunnsspeilet 1988; nr. 3: 3-6.

58. Bjartveit K. The effect of an advertising ban - who has the burden of proof? Proceedings Ninth World Conference on Tobacco and Health, Paris 1994 (under trykking).

59. Cancer in Norway 1992. Oslo: Kreftregisteret, Institutt for epidemiologisk kreftforskning, 1995.

60. Forty-eight World Health Assembly. WHA48.11 An international strategy for tobacco control. Genève: World Health Organization, 1995.

61. Sanner T. Hva koster sigarettrøykingen samfunnet? Tidsskr Nor Lageforen 1991; 111: 3420-2.

62. Fekjær HO. Alkohol og narkotika - myter og virkelighet. Oslo: Gyldendal, 1988.

63. Dødsårsaker 1988. Oslo: Statistisk sentralbyrå, 1990.

64. St.prp. nr 1 (1991-92) for budsjetterminen 1992, Sosialdepartementet.

65. Nilsen E. Smoking habits among children in Norway. Brit J Prev Soc Med 1959; 13: 5-13.

66. Nilsen E. Røykevaner og opplysningsarbeid. Oslo: Landsforeningen mot Kreft, 1964.

67. Aarø LE, Hauknes A, Berglund E-L. Smoking among schoolchildren 1975-80. Scand J Psychol 1981; 22: 161-9. 